Research Paper

\title{
Distribution and Statistical Aspects of Ostracoda from the Pulicat Lagoon, Tamil Nadu: Implications on Siltation and Microenvironment
}

\author{
S M HUSSAIN*, P MAHALAKSHMI and K RADHAKRISHNAN \\ Department of Geology, University of Madras, Guindy Campus, Chennai 600 025, India
}

(Received on 19 August 2017; Revised on 16 August 2018; Accepted on 16 August 2019)

\begin{abstract}
Ostracods are bivalved tiny Crustaceans; inhabit almost all types of aquatic environments. In order to study the systematic and distribution of recent brackish water Ostracoda from the Pulicat lagoon, near Chennai, Tamil Nadu, a total of twelve surface sediment samples and one core were collected from Pulicat lagoon. A total of a total of 37 ostracod taxa belonging to 24 genera, 14 families, 2 superfamilies, and 2 suborders of the order Podocopida have been identified. Among these, Cytherelloidea leroyi belong to suborder Platycopa and the remaining 36 species to suborder Podocopa are recorded from Pulicat lagoon.

Geochemical and sedimentological parameters such as $\mathrm{CaCO}_{3}$, Organic matter and sand-silt-clay ratio were estimated. An attempt has been made to study the relation between the sediment characteristics (the substrate of the Pulicat lagoon samples consists of sand and silty-sand) and Ostracoda population, and evaluate the favourable substrate for the population abundance in the area. From the distribution of Ostracoda, it is inferred that the sandy substrate is congenial sediment type for the population abundance and distribution. The implications of the proxies like Ostracod surface ornamentation, carapace and valve ratio and other environmental interpretations from the Pulicat lagoon are presented in this paper. The ratio between the carapaces and open valves of Ostracoda has been taken into consideration for determining the rate of sedimentation. Among a total of 1910 Ostracod shells recovered in surface and core, specimens 1469 are carapaces, while the remaining 441 specimens are open valves. Based on this observation, it may be concluded that a relatively rapid rate of sedimentation prevails in the Pulicat lagoon.
\end{abstract}

Keywords: Ostracoda; Sediment Characteristics; Sedimentation Rate; Pulicat Lagoon; Tamil Nadu

\section{Introduction}

Ostracods are found in freshwater and athalassic habitats ranging from temporary ponds, rice fields to rivers and deep lakes. Brackish water environments such as coastal saline lakes, coastal lagoons, mangrove environments and open estuaries also support a diverse range of these fauna. In the oceans, ostracods inhabit all environments from intertidal zones to open ocean depths up to 4000 meters (psychrospheric forms). Certain freshwater ostracods can tolerate extreme environmental conditions, which flourish in hot water or sulphur springs. Ostracods have several advantages since they cover the entire Phanerozoic time scale and occur in all aquatic environments down to abyssal depths in the oceans.
Salinity, water temperature, stability of the substrate and organic material are the major factors governing ostracod distribution in estuarine and shelf environments. Ostracod species diversity decreases very rapidly when water salinity exceeds $40 \%$. Ostracods are almost absent in coarse substrates of active hydraulic process such as wave turbulence, whereas in finer substrates rich in organic detritus they form nearly large populations.

Ostracods are abundant and diverse group of tiny Crustaceans with a long fossil record from the Ordovician to Recent. Ostracods are typically around one $\mathrm{mm}$ in size, laterally compressed and protected by a bivalve, chitinous or calcareous shell known as carapace. The hinge of the two "valves" is in the

*Author for Correspondence: E-mail:smhussain7@hotmail.com 
upper, dorsal region of the body. Most ostracods live burrowed in the substrate or epibenthic crawlers, others are nektonic.

\section{Study Area}

The proposed work envisages a detailed probe into microfaunal (Ostracoda) analysis of the sediments collected from Pulicat Lagoon near Chennai, Tamil Nadu. (Fig. 1). The Pulicat is the largest south Indian

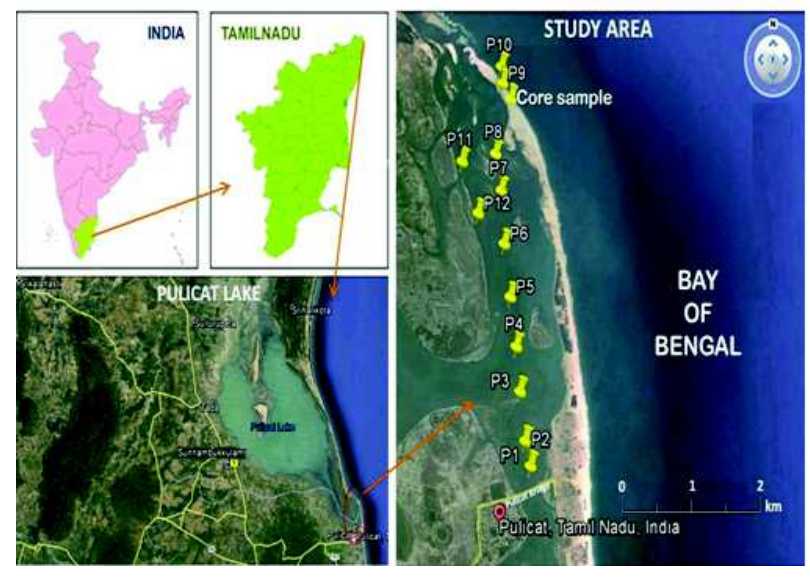

Fig. 1: Location map of the study area, Pulicat lagoon, north of Chennai, Tamil Nadu

coastal lake and a marshy mangrove wetland located in Tiruvallur District of Tamil Nadu and Nellore District of Andhra Pradesh. The Pulicat lake estuary is a shallow tropical lagoon that lies between $13^{\circ} 24^{\prime} 42^{\prime \prime}$ to $13^{\circ} 28^{\prime} 40^{\prime \prime} \mathrm{N}$ and $80^{\circ} 18^{\prime} 50^{\prime \prime}$ to $18^{\circ} 20^{\prime} 00^{\prime \prime} \mathrm{E}$ (Survey of India toposheet No. 66 C/7), aligned almost parallel to the Bay of Bengal. It extends over the Ponneri and Gummidipundi taluk of Thiruvallur district in Tamil Nadu and Sulurpet and Tada Taluk of Nellore district in Andhra Pradesh and covers an area of about 461 $\mathrm{km}^{2}$. The lake is separated from the Bay of Bengal by the barrier island of Sriharikota.

\section{Methodology}

To study the taxonomy and distribution of Recent Ostracoda from the Pulicat lagoon, a total of 12 surface sediment samples and one core were collected from Pulicat lagoon (Table 1). The length of the core $\left(13^{\circ} 27^{\prime} 42.87^{\prime \prime} \mathrm{N} \& 80^{\circ} 19^{\prime} 3.933^{\prime \prime} \mathrm{E}\right)$ retrieved is $75 \mathrm{~cm}$ and it is subsampled into 15 at a regular interval of $5 \mathrm{~cm}$. The sediment samples were collected with help of Van veen grab sampler by using a motor
Table 1: Geographical co-ordinates of Grab samples collected from the Pulicat Lagoon

\begin{tabular}{lccc}
\hline $\begin{array}{l}\text { Sample } \\
\text { No. }\end{array}$ & Latitude & Longitude & $\begin{array}{c}\text { Water depth } \\
(\mathrm{Ft})\end{array}$ \\
\hline 1 & $13^{\circ} 25^{\prime} 11.7^{\prime \prime} \mathrm{N}$ & $80^{\circ} 19^{\prime} 1.68^{\prime \prime} \mathrm{E}$ & 4.0 \\
2 & $13^{\circ} 25^{\prime} 23.82^{\prime \prime} \mathrm{N}$ & $80^{\circ} 19^{\prime} 11.94^{\prime \prime} \mathrm{E}$ & 4.1 \\
3 & $13^{\circ} 25^{\prime} 42.18^{\prime \prime} \mathrm{N}$ & $80^{\circ} 19^{\prime} 9.84^{\prime \prime} \mathrm{E}$ & 5.5 \\
4 & $13^{\circ} 25^{\prime} 5.58^{\prime \prime} \mathrm{N}$ & $80^{\circ} 19^{\prime} 6.96^{\prime \prime} \mathrm{E}$ & 12.0 \\
5 & $13^{\circ} 26^{\prime} 18.06^{\prime \prime} \mathrm{N}$ & $80^{\circ} 19^{\prime} 5.76^{\prime \prime} \mathrm{E}$ & 7.0 \\
6 & $13^{\circ} 26^{\prime} 38.7^{\prime \prime} \mathrm{N}$ & $80^{\circ} 19^{\prime} 3.12^{\prime \prime} \mathrm{E}$ & 7.0 \\
7 & $13^{\circ} 26^{\prime} 59.7^{\prime \prime} \mathrm{N}$ & $80^{\circ} 19^{\prime} 1.92^{\prime \prime} \mathrm{E}$ & 8.0 \\
8 & $13^{\circ} 27^{\prime} 14.28^{\prime \prime} \mathrm{N}$ & $80^{\circ} 18^{\prime} 59.34^{\prime \prime} \mathrm{E}$ & 1.5 \\
9 & $13^{\circ} 27^{\prime} 43.26^{\prime \prime} \mathrm{N}$ & $80^{\circ} 19^{\prime} 4.14^{\prime \prime} \mathrm{E}$ & 3.5 \\
10 & $13^{\circ} 27^{\prime} 49.8^{\prime \prime} \mathrm{N}$ & $80^{\circ} 19^{\prime} 3.12^{\prime \prime} \mathrm{E}$ & 4.0 \\
11 & $13^{\circ} 27^{\prime} 5.76^{\prime \prime} \mathrm{N}$ & $80^{\circ} 18^{\prime} 37.68^{\prime \prime} \mathrm{E}$ & 2.5 \\
12 & $13^{\circ} 25^{\prime} 2.64^{\prime \prime} \mathrm{N}$ & $80^{\circ} 19^{\prime} 13.26 " \mathrm{E}$ & 2.0 \\
Core I & $13^{\circ} 27^{\prime} 42.87^{\prime \prime}$ & $80^{\circ} 19^{\prime} 3.93^{\prime \prime}$ & \\
\hline
\end{tabular}

boat. The Ostracod taxa were separated from the sediments applying standard micropaleontological techniques. Apart from the taxonomy of the species, their morphological, micro-structural characters are critically studied using stereo-binocular microscope and SEM (Scanning Electron Microscope). The taxonomy and systematics were dealt using Ostracod treatise by Hartmann \& Puri (1974) and other recent literature. Distribution pattern of individual taxon was examined and their sediment relationship was determined for ecologic/environmental interpretation. Sand-silt-clay ratio estimation was carried out using the procedure of Krumbein \& Pettijohn (1938). Organic matter was determined by titration method of Gaudette et al. (1974). Estimation of $\mathrm{CaCO}_{3}$ was made by adopting the procedure proposed by Loring and Nota (1973).

\section{Results and Discussion}

\section{Systematic Paleontology}

The Ostracod taxonomy was dealt using the classification proposed by Hartmann and Puri (1974) and accordingly a total of 37 ostracod taxa belonging to 24 genera, 14 families, 2 superfamilies, and 2 suborders of the order Podocopida have been identified. Among these, Cytherelloidea leroyi belonging to suborder Platycopa and the remaining 
36 species to suborder Podocopa are recorded from Pulicat lagoon (Table 2). The SEM photomicrographs of the species depicting different views are shown in Plates 1-3.
The occurrence of shallow inner shelf species such as $A$. reitculataindoaustralica, $K$. reticulata, $K$. whatleyi, L. coralloides and Xestoleberisvariegata in the lagoon may be due to the tidal

Table 2: Taxonomic chart of the Ostracoda in Pulicat Lagoon

\begin{tabular}{|c|c|c|c|c|c|}
\hline Order & Suborder & Superfamily & Family & Genus & Species \\
\hline \multirow[t]{24}{*}{ Podocopida } & Platycopa & & Cytherellidae & Cytherelloidea & Cytherelloidea leroyi \\
\hline & Podocopa & Cytheracea & Cytheridae & Hemicytheridea & $\begin{array}{l}\text { Hemicytheridea bhatiai } \\
\text { H. khoslai } \\
\text { H. paiki }\end{array}$ \\
\hline & & & & Neomonoceratina & $\begin{array}{l}\text { Neomonoceratina iniqua } \\
\text { N. jaini } \\
\text { N. porocostata } \\
\text { N. delicata }\end{array}$ \\
\hline & & & & Jankeijcythere & Jankeijcythere mckenziei \\
\hline & & & Sinocytheridae & Neosinocythere & Neosinocythere dekrooni \\
\hline & & & Leptocytheridae & Callistocythere & Callistocythere flavidofuscaintricatoides \\
\hline & & & & Tanella & Tanella gracilis \\
\hline & & & Cushmanideidae & Cushmanidea & Cushmanidea sp. \\
\hline & & & Trachyleberididae & Actinocythereis & Actinocythereis scutigera \\
\hline & & & & Stigmatocythere & Stigmatocythere indica \\
\hline & & & & Alocopocythere & Alocopocythere reticulata indoaustralica \\
\hline & & & & Chrysocythere & Chrysocythere keiji \\
\hline & & & & Keijella & $\begin{array}{l}\text { Keijella reticulata } \\
\text { K. whatlyei }\end{array}$ \\
\hline & & & & Lankacythere & $\begin{array}{l}\text { Lankacythere coralloides } \\
\text { Lankacythere } \mathrm{sp} .\end{array}$ \\
\hline & & & & Basslerites & Basslerites liebaui \\
\hline & & & Hemicytheridae & Caudites & Caudites javana \\
\hline & & & Loxoconchidae & Loxoconcha & $\begin{array}{l}\text { Loxoconcha megapora indica } \\
\text { L. tekkaliensis } \\
\text { L. gruendeli }\end{array}$ \\
\hline & & & Cytheruridae & Semicytherura & $\begin{array}{l}\text { Semicytherura contraria } \\
\text { Semicytherura } \mathrm{sp} .1 \\
\text { Semicytherura } \mathrm{sp} .2\end{array}$ \\
\hline & & & & Paijenborchellina & $\begin{array}{l}\text { Paijenborchellina prona } \\
\text { P. indoarabica } \\
\text { Paijenborchellina sp. }\end{array}$ \\
\hline & & & Xestolebrididie & Xestoleberis & Xestoleberis variegata \\
\hline & & & Uncertain & Kalingella & Kalingella mckenziei \\
\hline & & Cypridacea & Cyprididae & Cypridopsis & Cypridopsisobesa \\
\hline & & & Pontocyprididae & Propontocypris & $\begin{array}{l}\text { Propontocypris (Schedopontocypris) } \\
\text { bengalensis }\end{array}$ \\
\hline & & & Candonidae & Phlyctenophora & Phlyctenophora orientalis \\
\hline
\end{tabular}




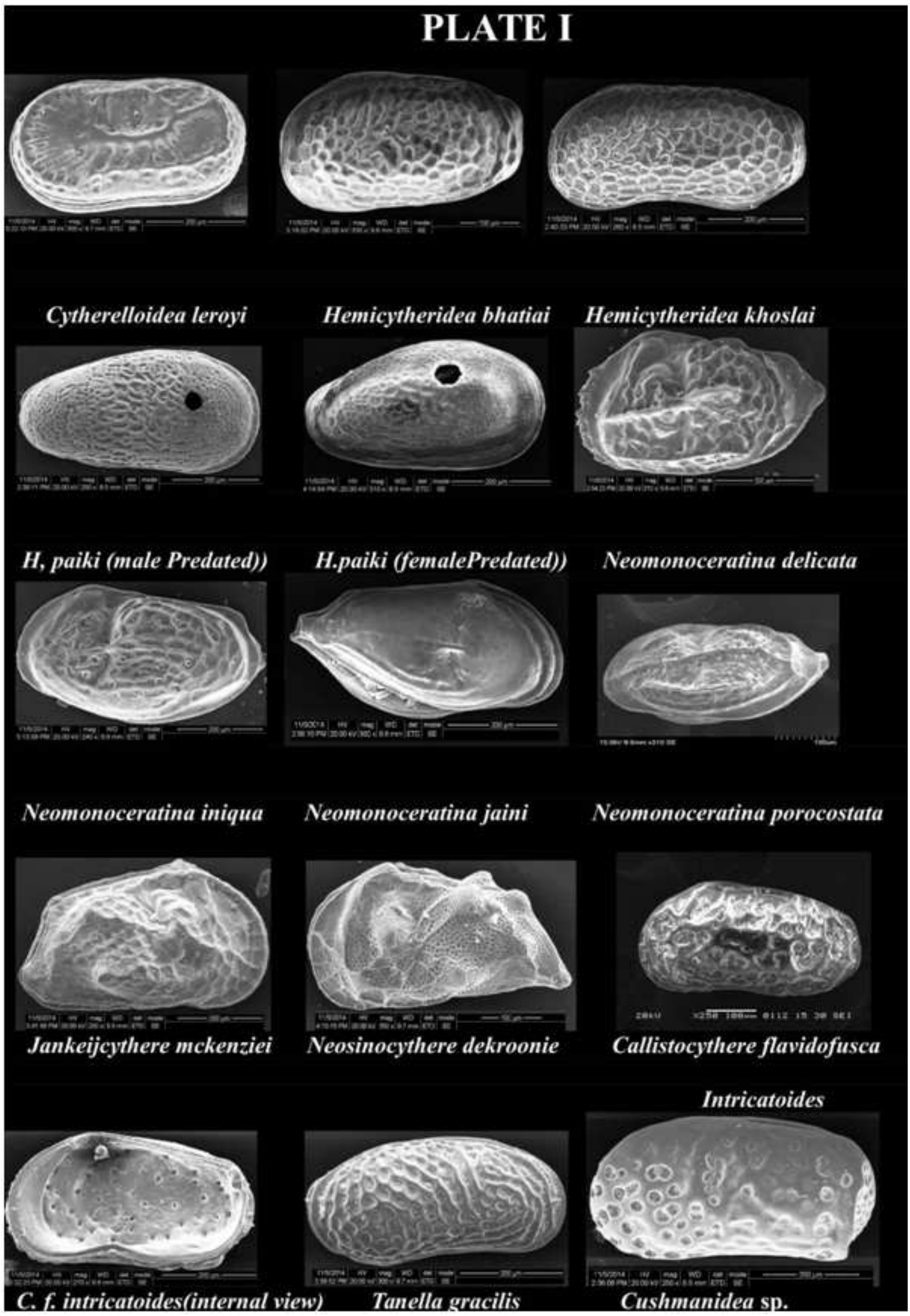




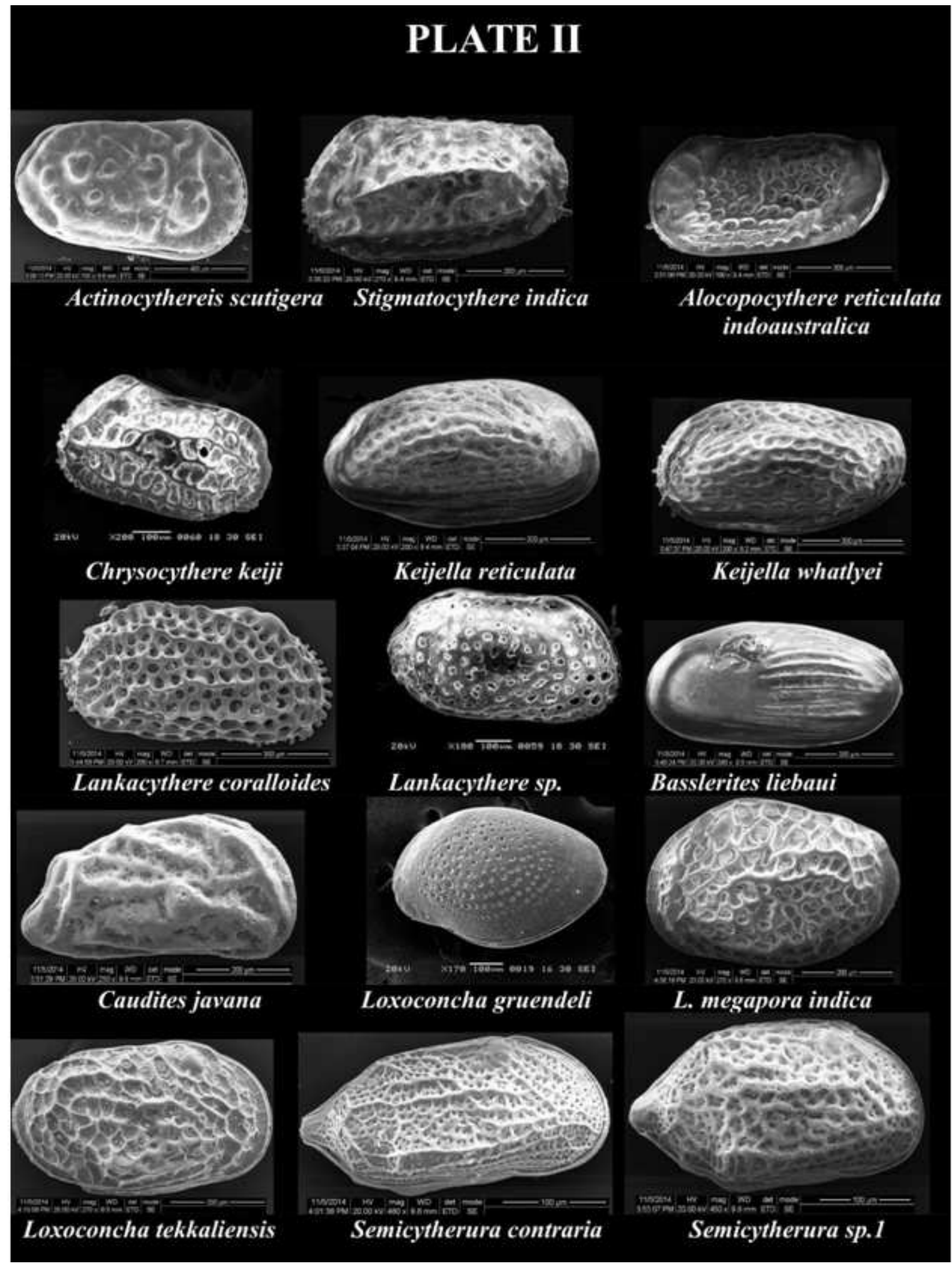




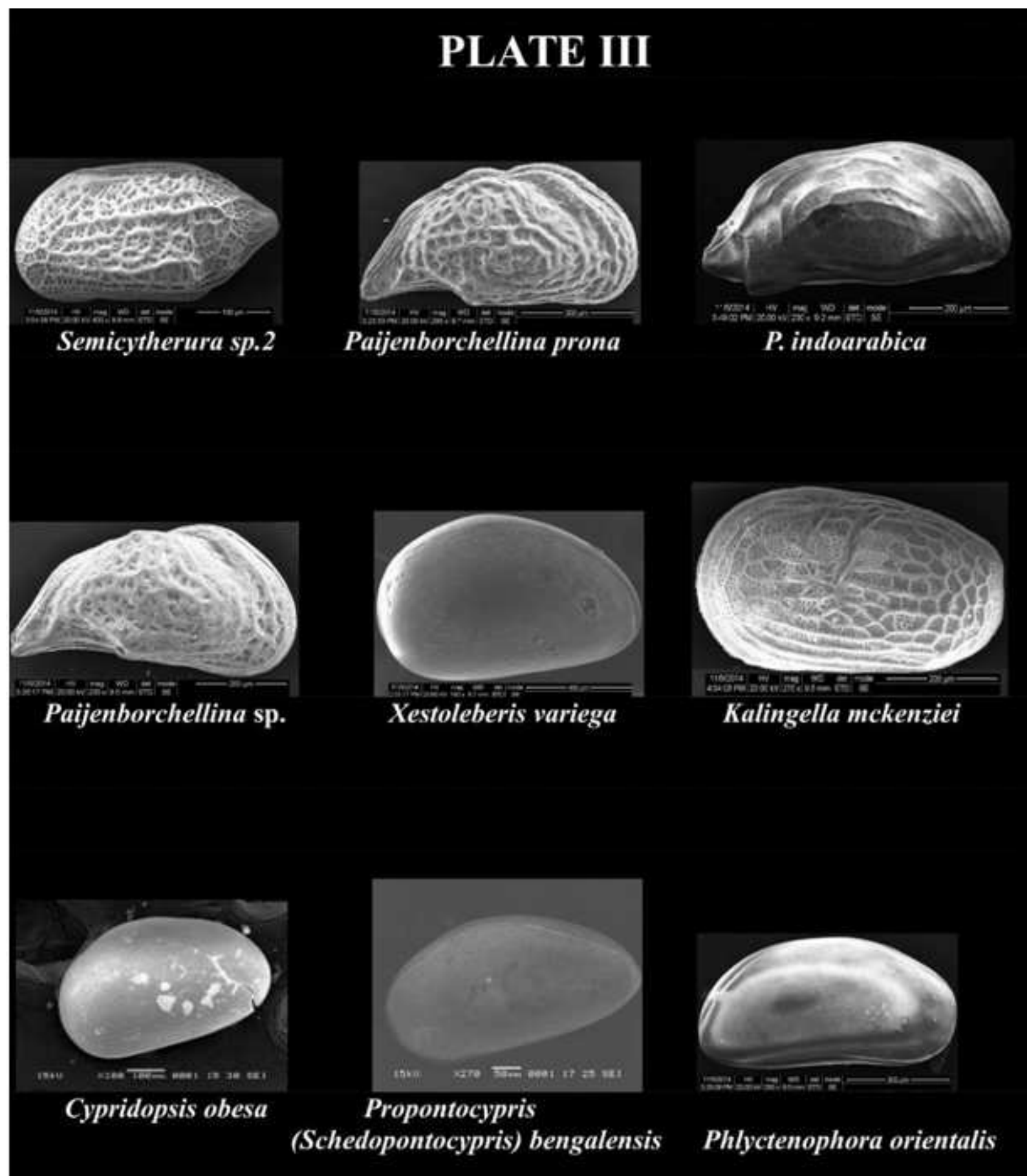

influence. The species $H$. bhatiai, J. mckenziei, $L$. megaporaindica and $N$. dekrooni are typical brackish water species. The medium grained siltysand to sandy substrate loving species with moderate ornamentation such as reticules, ridges and punctae and nodes are recorded in the Pulicat lagoon.

\section{Sediment Characteristics}

Organic Matter : The rate of deposition of organic matter depends upon the production within the upper layers and the rate of destruction during descent through the water column. Abundant supply of oxygen will cause decomposition of the organic matter that 
has reached the bottom. The sediment texture also plays a role, i.e., comparatively coarse grained sediments are more permeable than fine grained ones and hence, the latter are more suitable for preservation of organic matter.

According to Sverdrup et al. (1942), the under mentioned conditions will favour the formation of sediments rich in organic matter: a) good supply of organic matter b) relatively, a rapid rate of accumulation of organic material, especially of fine grained sediments, and c) less supply of oxygen to the water in contact with the sediments. Whatley and Quanhong (1987, 1988) considered the nature of substrate to be the main controlling factor for ostracod abundance; highest values occur in association with medium to coarse sand rich in organic debris, and lower values with gravels and those sands poor in carbonate and dominated by quartz. From offTuticorin, Gulf of Mannar, Hussain et al. (1997) observed that a relative decrease in the organic matter content of the sediments favours a maximum population of Ostracoda. In the present study, organic matter content was determined for all the 12 surface samples and core samples collected. The organic matter content in the surface sediments samples range from $2.47 \%$ to $4.12 \%$ and subsurface samples range from $0.05 \%$ to $2.4 \%$ (Table $3 \mathrm{a} \& 3 \mathrm{~b}$, Fig. $2 \mathrm{~A}$ and B).The higher organic matter appears favouring the maximum population.

Calcium Carbonate : Calcium carbonate is an important component of aquatic sediment (Ramesh and Anbu, 1996). The precipitation of calcium carbonate in sediment takes place in many different ways. It is deposited either by inorganic or organic agents, or precipitated by physical means from colloidal solutions, some may be precipitated from suspension, and some coarse-grained calcium carbonate is carried by river run-off after weathering and settles down in the sediment.Sebastian et al. (1990), in their study on sediments of Mahe estuary, West Coast of India, observedthat the major sources of carbonate in the sediments of the study area are the shells and broken shell fragments of organisms, molluscs and also due to dilution of biogenic calcite by detrital material in the sediments. The association of sand particles with $\mathrm{CaCO}_{3}$ indicates the major contribution of shell fragments to the sand fraction.

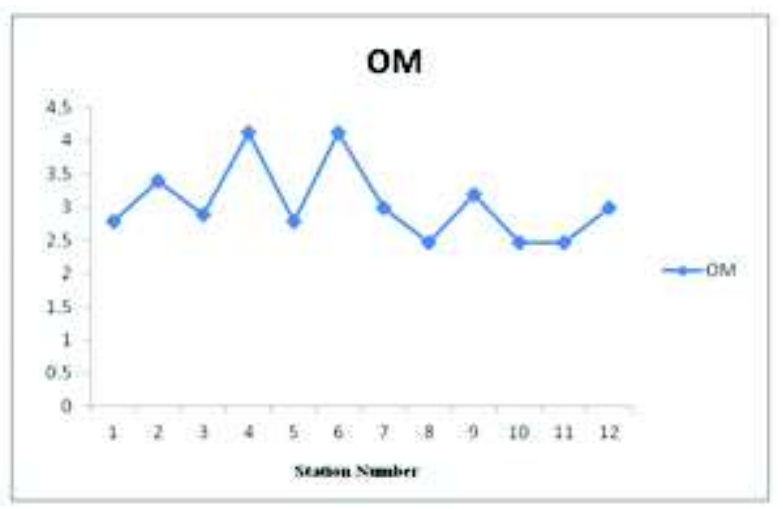

Fig. 2A: Distribution of Organic matter in the surface samples of Pulicat lagoon

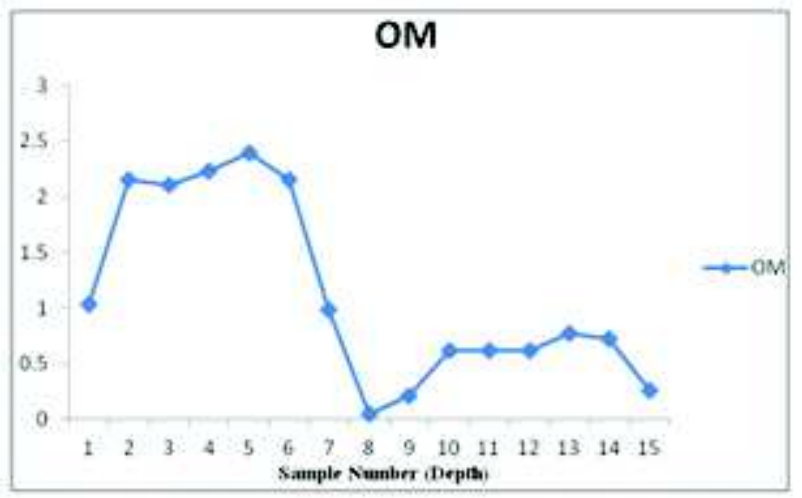

Fig. 2B: Distribution of Organic matter in the sub-surface samples of Pulicat lagoon

In present study the calcium carbonate content was determined for all the 12 surface samples and core samples collected in thePulicat lagoon. The calcium carbonate content of surface samples range from $6 \%$ to $17 \%$ and for subsurface samples it range from $0.5 \%$ to $4 \%$ (Table $3 a$ \& $3 b$, Fig. $3 A$ and B).

\section{Discussion}

\section{Substrate}

The sediment texture, down Core variation and their implications on physico-chemical parameters of the Core samples have been studied in detail. The grain size distribution in the Core sediments is important in understanding the depositional environment history. There are local variations in sediment textures (such as Sand-silt- clay ratio) distribution from Core to Core, and also within the Core at different depths. The lack of substantial river input and the elongated shape of the lagoon are responsible for the moderate mud 


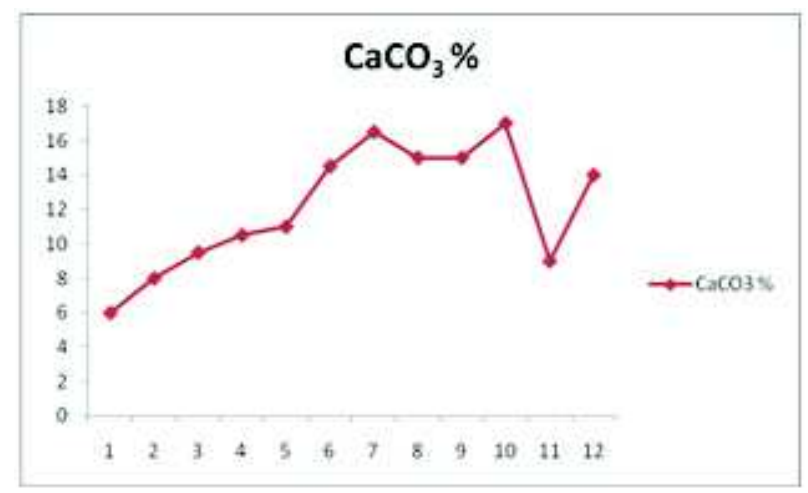

Fig. 3A: Distribution of $\mathrm{CaCo}_{3}$ in the surface samples of Pulicat lagoon

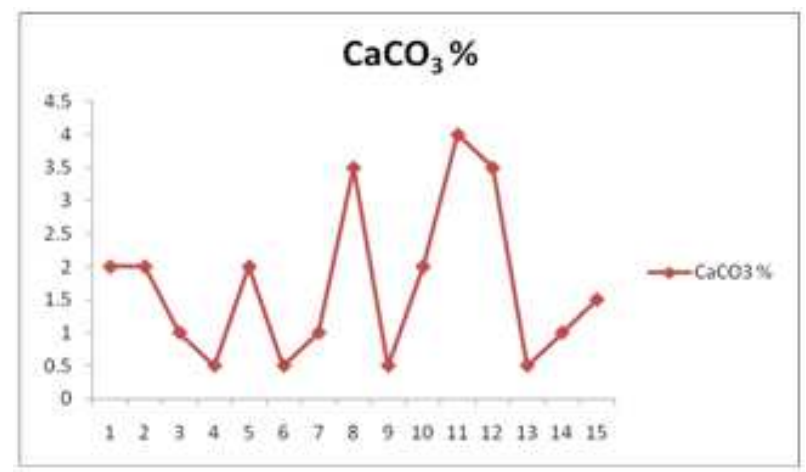

Fig. 3B: Distribution of $\mathrm{CaCo}_{3}$ in the sub-surface samples of Pulicat lagoon

content (silt + clay) in core I and II. As the lagoon is trending east-west along the coast line of southeast cost of India, the marine input of mud is due to the northerly current acting in Bay (Selvaraj et al. 2005).

Puri (1966) stated that the nature of bottom sediments such as grain size, sorting coefficient and the presence or absence of bottom vegetation, affect the distribution of ostracods. Consequently, diverse sedimentary facies support distinct ostracod assemblages. According to Annapurna and Rama Sarma (1982), ostracods prefer areas high in sand and clay rather than areas rich in silt, as in the Bimili backwaters and Balacheruvu tidal stream. Similar relationship has also been observed in marine marginal water bodies of other localities (Elofson, 1941; Benson, 1959).

Buzas (1965) stated that since clay size particles tend to bind the organic matter, the clay content of the sediment is considered to be an important factor for the distribution and quantity of benthonic organisms; and in Long Island Sound, where the silt and clay content of the sediment is less than $2 \%$, there are usually no foraminifera. However, Murray (1968) found no obvious correlation between the nature of substrate and the composition of living fauna, in Christ Church Harbour area.

The substrate sediment texture has a control on the kind of ostracod fauna that can colonise a particular sediment type (Brasier, 1980). The texture stability of sediment composing the substrate exerts a strong influence on marine ostracods.

The relative abundance of sand, silt and clay in the sediments from each of the 12 surface samples and 15 subsurface sediment samples has been studied. Trefethen's (1950) textural nomenclature has been used to describe the sediment types of the present area. Taking into consideration the 12 surface samples and 1 coresample, the substrate of the Pulicat lagoon samples consists of sand, siltysand (Fig. 4A and B).

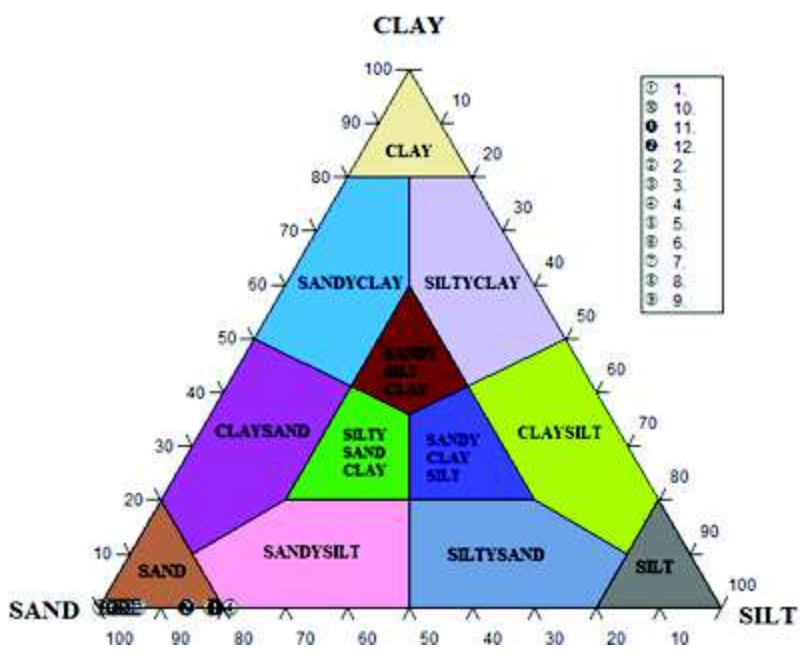

Fig. 4A: Trilinear plots of sand, silt and clay ratio for the surface samples of Pulicat lagoon (after Trefethen, 1950)

The sand, silt and clay ratio for the surface sediments samples range from $78 \%$ to $99.6 \%, 0.35 \%$ to $21.14 \%$, $0.03 \%$ to $0.09 \%$ and for subsurface samples it ranges from $96.27 \%$ to $99.32 \%, 0.66 \%$ to $3.72 \%, 0.01 \%$ to $0.04 \%$ (Table $3 \mathrm{a}$ and $\mathrm{b}$ ).

\section{Carapace-Value Ratio}

During the last four decades, the application of statistical data on Ostracoda, such as juveniles and adults; closed and isolated valves; males and females; right and left valves; smooth and ornamented forms, 


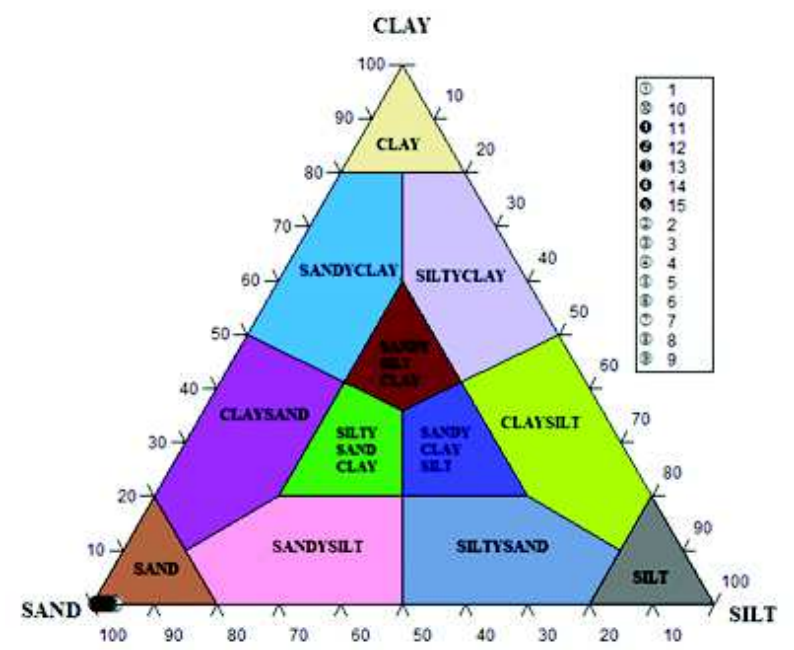

Fig. 4B: Trilinear plots of sand, silt and clay ratio for the sub-surface samples of Pulicat lagoon (after Trefethen, 1950)

Table 3a: Estimated values of $\mathrm{CaCO}_{3}$, OM, Sand, Silt and Clay percentages of surface sediment samples of Pulicat lagoon

\begin{tabular}{lccccc}
\hline S.No. & $\begin{array}{c}\mathrm{CaCO}_{3} \\
\%\end{array}$ & $\begin{array}{c}\mathrm{OM} \\
\%\end{array}$ & $\begin{array}{c}\mathrm{SAND} \\
\%\end{array}$ & $\begin{array}{c}\text { SILT } \\
\%\end{array}$ & $\begin{array}{c}\text { CLAY } \\
\%\end{array}$ \\
\hline 1. & 6 & 2.78 & 94.28 & 5.66 & 0.06 \\
2. & 8 & 3.39 & 97.37 & 2.58 & 0.05 \\
3. & 9.5 & 2.88 & 97.51 & 2.44 & 0.05 \\
4. & 10.5 & 4.12 & 78.83 & 21.14 & 0.03 \\
5. & 11 & 2.78 & 81.87 & 18.04 & 0.09 \\
6. & 14.5 & 4.12 & 96.4 & 3.51 & 0.09 \\
7. & 16.5 & 2.98 & 93.62 & 6.32 & 0.06 \\
8. & 15 & 2.47 & 95.47 & 4.48 & 0.05 \\
9. & 15 & 3.19 & 99.6 & 0.35 & 0.05 \\
10. & 17 & 2.47 & 98.22 & 1.73 & 0.05 \\
11. & 9 & 2.47 & 81.35 & 18.58 & 0.07 \\
12. & 14 & 2.98 & 85.85 & 14.08 & 0.07 \\
Average & 12.16 & 3.05 & 91.69 & 8.24 & 0.05 \\
Max & 17 & 4.12 & 99.6 & 21.14 & 0.09 \\
Min & 6 & 2.47 & 78.83 & 0.35 & 0.03 \\
\hline
\end{tabular}

etc., besides colour variation, pyritisation and predation, to interpret the environment of deposition, and rate of deposition of sediments has attained importance. The carapace of few ostracods has smooth surface, and devoid of any sculpture. However, in many species, the carapaces are with simple to complex surface
Table 3b: Estimated values of $\mathrm{CaCO}_{3}$, OM, Sand, Silt and Clay percentages of sub-surface sediment samples of Pulicat lagoon

\begin{tabular}{lccccc}
\hline $\begin{array}{l}\text { Depth in } \\
\mathrm{cm}\end{array}$ & $\begin{array}{c}\mathrm{CaCO}_{3} \\
\%\end{array}$ & $\begin{array}{c}\mathrm{OM} \\
\%\end{array}$ & $\begin{array}{c}\text { SAND } \\
\%\end{array}$ & $\begin{array}{c}\text { SILT } \\
\%\end{array}$ & $\begin{array}{c}\text { CLAY } \\
\%\end{array}$ \\
\hline $0-5$ & 2 & 1.03 & 99.32 & 0.67 & 0.01 \\
$5-10$ & 2 & 2.16 & 98.77 & 1.21 & 0.02 \\
$10-15$ & 1 & 2.11 & 98.77 & 1.22 & 0.01 \\
$15-20$ & 0.5 & 2.23 & 98.46 & 1.52 & 0.02 \\
$20-25$ & 2 & 2.4 & 98.28 & 1.7 & 0.02 \\
$25-30$ & 0.5 & 2.16 & 97.69 & 2.3 & 0.01 \\
$30-35$ & 1 & 0.98 & 97.52 & 2.46 & 0.02 \\
$35-40$ & 3.5 & 0.05 & 96.27 & 3.72 & 0.01 \\
$40-45$ & 0.5 & 0.21 & 98.83 & 1.15 & 0.02 \\
$45-50$ & 2 & 0.62 & 97.57 & 2.4 & 0.03 \\
$50-55$ & 4 & 0.62 & 99.27 & 0.7 & 0.03 \\
$55-60$ & 3.5 & 0.62 & 99.3 & 0.66 & 0.04 \\
$60-65$ & 0.5 & 0.77 & 98.08 & 1.9 & 0.02 \\
$65-70$ & 1 & 0.72 & 98.48 & 1.49 & 0.03 \\
$70-75$ & 1.5 & 0.26 & 98.83 & 1.15 & 0.02 \\
Average & 1.6 & 1.12 & 98.36 & 1.61 & 0.02 \\
Max & 4 & 2.4 & 99.32 & 3.72 & 0.04 \\
Min & 0.5 & 0.05 & 96.27 & 0.66 & 0.01 \\
\hline & & & & & \\
\hline
\end{tabular}

ornamentation. Hence, surface ornamentation serves as direct evidence for ecological interpretations, which can be studied with the help of Scanning Electron Microscope (SEM) photographs of the specimens. Individuals living in carbonate reef environments have much thicker secondary ornamentation compared to individuals living in other environments. Ornamentation also reflectsthe grain size of the sediment. Ostracod carapace-valve ratio helps in deducing siltation (sedimentation) of an area.

The carapaces in ostracods open up and intense bacterial activity separates the valves. In an environment where deposition of the sediment is low, the carapaces are likely to open up by bacterial action. But, in an environment where deposition is very rapid, the carapaces will sink into the soft bottom and will be quickly covered by sediments. Thus, the carapaces will have less chances of opening up, after the destruction of muscles and ligaments.

The usage of carapace-valve ratio to yield palaeoecological information was pioneered by 
Pokorny (1965). Oertli (1971) reviewed Pokorny's work and summarized that when the ratio is high, the sedimentation is rapid, which minimizes disarticulation of carapaces into separate valves. With sufficiently rapid burial, organic matter is not absorbed by mineral particles and so retains potential for conversion into hydrocarbons. Honnappa and Venkatachalapathy (1978) studied the carapace-valve ratio to interpret the rate of deposition of sediments in the Mangalore Harbor area. They found that the occurrence of separate shells is much more in number than the closed shells (ratio being 24:1). According to them, this is indicative of a slow rate of sedimentation in more agitating waters. From a study of the ostracod assemblages in the Pulicat lagoon sediments, Sreenivas et al. (1991) found the percentage of complete shells to be more in number when compared to the separate ones. According to them, it is an indication of comparatively rapid rate of sedimentation. While studying various aspects of ostracod assemblages in the Gulf of Mannar, off Tuticorin, Hussain et al. (2002) observed the ratio between the carapaces and open valves for evaluating the rate of sedimentation and found that the same is faster (or rapid). The ratio of carapaces to valves in the inner shelf of Gulf of Mannar has been estimated by him (op. cit.) to be 4:1. An almost similar estimate was determined by Sridhar (1996) from the Palk Bay where he observed the carapace to valve ratio to be 5:1, indicative of a fairly faster rate of sedimentation. Hussain and Rajeshwara Rao (1996) observed generally more number of closed carapaces than the open valves along the east coast inner shelf sediments, while the number is so less from the sediments off the west coast. They (op. cit.), on the above observation, inferred that the rate of sedimentation is rapid in the east coast and slow in the west coast of India, which they attributed to more number of streams/rivers flowing and debouching the sediments into the Bay of Bengal. From off Karikkattukuppam, Bay of Bengal, Hussain et al. (2004) observed a slow rate of sedimentation in the study area.

In present study, a total of 1910 Ostracod specimens are recovered from surface and core (subsurface) samples, of which 1469 specimens are carapaces, while the remaining 441 specimens are open valves (Tables 4a-b). The distribution of carapaces and open valves, for all the stations put together, reveals that the carapaces outnumbered open valves.

An environmental analysis was made and ostracod abundances were compared with different environmental parameters. Significantly represented $(>10 \%)$ in stressing conditions, i.e., moderate salinity fluctuations, moderate to high hydrodynamic levels, low organic matter contents, moderate to well-sorted sediments with high percentages of medium sands and low to very low ostracoda diversity. These differences make clear the potential of these microcrustaceans as environmental tracers in these transitional areas. Population abundance is more in siltysand and sandysilt. Salinity has proved to have a direct effect on the number of species and abundance of specimens in these marginal marine environments. Ostracoda diversity is low in these habitats, although abundance may be remarkably high, with one to two species dominating. In the Pulicat lagoon also only three species namely, $H$. bhatiai are dominant and persistently distributed. The distribution and abundance of ostracods in shallow marine sediments to lagoon are related to environmental parameter (ostracoda diversity and density, grain size and depth).

Marginal marine environments like marsh, rivers, coastal lagoons, deltas, estuaries, mangrove islands, salt marshes and fluvial marine assemblages are characterized by several species which are peculiar to these environments. Environmental factors which control the distribution of shallow water ostracods seem to be salinity, temperature, sediments and organic matter.

Marginal - marine environment challenging physicological problems for most organisms, including ostracods, since they may have to survive marked environmental changes over very short periods. Ostracods diversity is often low in these habitats, although abundance may be remarkably high, with one or two species dominating. Ostracods are another meiofaunal group with increasing uses as biomonitors of stressed conditions in Recent and Quaternary environments (Boomer and Eisenhauer, 2002).

\section{Conclusion}

To know the siltation and microenvironment of the Pulicat Lagoon, Tamil Nadu, a total of 12 surface sediment samples were collected from the lagoon in the water depth ranges from 1.5 to $12 \mathrm{ft}$. In addition, 
Table 4a: Distribution of carapaces and open valves Ostracoda in the surface sediment samples of Pulicat lagoon

\begin{tabular}{lccc}
\hline S.No. & Carapace & Open valve & Total population \\
\hline 1 & 57 & 2 & 59 \\
2 & 91 & 8 & 99 \\
3 & 64 & 44 & 108 \\
4 & 113 & 9 & 122 \\
5 & 169 & 24 & 193 \\
6 & 203 & 7 & 210 \\
7 & 207 & 5 & 212 \\
8 & 166 & 8 & 174 \\
9 & 1 & 0 & 1 \\
10 & 8 & 0 & 8 \\
11 & 46 & 2 & 48 \\
12 & 230 & 4 & 234 \\
Total & 1355 & 113 & 1468 \\
\hline
\end{tabular}

Table 4b: Distribution of Carapaces and open valves Ostracoda in the of sub surface sediment samples of Pulicat lagoon

\begin{tabular}{lccc}
\hline Depth in cm & Carapace & Open valve & Total population \\
\hline $0-5$ & 5 & 10 & 15 \\
$5-10$ & 1 & 1 & 2 \\
$10-15$ & 1 & 6 & 7 \\
$15-20$ & 34 & 101 & 135 \\
$20-25$ & 17 & 101 & 118 \\
$25-30$ & 40 & 61 & 101 \\
$30-35$ & 5 & 23 & 28 \\
$35-40$ & 3 & 6 & 9 \\
$40-45$ & 4 & 8 & 12 \\
$45-50$ & 1 & 3 & 4 \\
$50-55$ & 0 & 0 & 0 \\
$55-60$ & 1 & 3 & 4 \\
$60-65$ & 2 & 3 & 5 \\
$65-70$ & 0 & 2 & 2 \\
$70-75$ & 0 & 0 & 0 \\
Total & 114 & 328 & 442 \\
\hline
\end{tabular}

one core sample was also collected. From the sediments, 37 ostracod taxa belonging to 24 genera, 14 families, 2 superfamilies, and 2 suborders of the order Podocopida have been identified. The occurrence of shallow inner shelf species such as $A$. reticulata indoaustralica, $K$. reticulata, $K$. whatleyi, L. Coralloides and Xestoleberis variegata in the lagoon may be attributed to the tidal influence. The species $H$. bhatiai, J. mckenziei, L. megaporaindica and $N$. dekrooni are typical brackish water species abundantly distributed in the lagoon. Most of the species exhibit moderately ornamented with reticules, ridges, punctae and nodes reflecting their congenial medium grained siltysand to sandy substrate. The marine biofacies is identified near the mouth of the estuary and the brackish water biofacies is found out in the middle of the estuary from the distribution of Ostracod fauna in the lagoon.

The sediment textural analysis reveals a medium energy environmental condition of deposition of sediments in the lagoon. The ratio between the carapaces and open valves of Ostracoda has been taken into consideration for determining the relative rate of siltation in the study area. From this study, it is concluded that a comparatively faster rate of sedimentation prevails in the Pulicat lagoon, especially during the monsoon periods preferably by the rivers Arani and Kalangi which bring and debouch the sediment into the Pulicat lagoon. Since the siltation is more in the Pulicat lagoon, periodically desiltation and dredging activities are being carried out at the mouth and middle portion of the lagoon.

\section{Acknowledgement}

Authors are highly thankful to CPEPA-UGC project for financial support. Authors thank Prof. and Head, Department of Geology, University of Madras, for the facilities.

\section{References}

Ahmed M, Neale J W and Siddiqui Q A(1991) Tertiary Ostracoda from the Lindi area, Tanzania Bull Br Mus Nat Hist (Geol) 46 175-270

Annapurna C and Rama Sarma D V (1982) Sediment-ostracod relationship in the Bimili backwaters and Balacheruvu tidal stream Proc Ind Acad Sci (Anim Sci) 91 297-303

Boomer I and Eisenhauer G (2002) Ostracod faunas as palaeoenvironmental indicators in marginal marine environments. In: Holmes $\mathrm{J}$ and Chivas A (Eds.), The Ostracoda: Applications in Quaternary Research Geophysical Monograph 131 135-149

Brasier M D (1980) Microfossils, George Allen and Unwin Ltd., London, 193p 
Buzas MA(1965) The distribution and abundance of foraminifera in Long Island Sound Smith Misc Coll 149 Publ No 4604 $1-89$

Elofson O (1941) Zurkenntnis der marionen Ostracodenschwedensmitbesonderer Berucksichtingung des Skageraks Zool Bidr Uppsala Univ 19 215-534

Gaudette H E, Flight W R, Toner L and Folger D W (1974) An inexpensive titration method for the determination of organic carbon in recent sediments J Sed Petrol 44249 253

Hartmann G and Puri H S (1974) Summary of Neontological and Palaeontological classification of Ostracoda Mitt Hamburg Zool Mus Inst 70 7-73

Honnappa and Venkatachalapathy V (1978) Paleoecological and ecological interpretations of sediments of Mangalore Harbour area, west coast of India, on the basis of colour variation of ostracod shells Curr Sci 47 772-773

Hussain S M, Mohan S P and Manivannan V (2002) Microenvironmental inferences of Recent benthic ostracoda from the Gulf of Mannar, off Tuticorin, southeast coast of India Proc National Seminar on Management of Natural Resources 23-43

Hussain and Kalaiyarasi (2013) Distribution of Ostracoda in the Mullipallam lagoon, near Muthupet, Tamil Nadu, southeast coast of India - Implications on microenvironment. (Chapter 11) In: Climate Change and coastal and Island Vulnerability (Eds. Sundaresan J, Sreekesh S, Ramanathan A L, Sonnenschein L and Boojh R, Capital Publishing Co., (India), (ISBN: 978-93-81891-02-5), pp.166-168

Hussain S M and Rajeshwara Rao N (1996) Faunal affinity, zoogeographic distribution and review on Recent Ostracoda from the east and west coasts of India Bull Pure Appl Sci $1537-50$

Hussain S M, Ravi G, Mohan S P and Rajeshwara Rao N (2004) Recent benthic Ostracoda from the Bay of Bengal, off Karikkattukuppam (near Chennai), southeast coast of India - Implication on microenvironments Journal of Environmental micropaleontology, Microbiology and Meiobenthology (JEMMM) 1 105-121

Joy J A and Clark D L (1977) The distribution, ecology and systematics of the benthic ostracods of central Arctic Ocean Micropal 23 129-154

Krumbein W C and Pettijohn F J (1938) Manual of Sedimentary Petrography, D. Appleton Century Co. Inc., New York, $549 \mathrm{p}$

Loring D H and Nota D J G (1973) Morphology and sediments of the Gulf of St. Lawrence J Fish Res Board Canada Bull 182147
Madhusudana Rao Ch and Murthy P S N (1968) Studies on the shelf sediments of the Madras coast Bull Nat Inst Sci India 38 442-448

McKenzie and Guha (1987) A comparative analysis of Eocene/ Oligocene boundary Ostracoda from south-eastern Australia and India with respect to their usefulness as indicators of petroleum potential Trans Roy Soc, $S$ Australia III 15-23

Mahalakshmi and Hussain (2015) Distribution of Ostracods from Pazhaverkadu (Pulicat Lagoon), Tamil Nadu, India (Chapter-16). In: lakes and wetlands, Vasudeven S et al., (eds.) Partridge India, (ISBN 978-1-4828-4545-7) 268287

Murray J W (1968a) The living Foraminiferida of Christchurch Harbour, England Micropal 148396

Oertli H J (1971) The aspects of ostracod faunas - a possible new tool in petroleum sedimentology Bull Centre Rech PauSNPA 5 137-151

Pokorny V (1965) Principles of Zoological Micropaleontology, 2, Pergamon Press, London, 465 (Translation of German edition)

Puri H S (1966) Ecologic and distribution of Recent Ostracoda Proc Symp Crustacea Pt I Mar Biol Assoc India Mandapam 457-495

Rajamanickam G V and Gujar A R (1984) Sediment depositional environments in some bays in Central West coast of India Ind Jour of Mar Sci 14 13-19

Rasheed D A and Ragothaman V (1978) Ecology and distribution of Recent foraminifera from the Bay of Bengal, off Porto Novo, Tamil Nadu State, India Proc VII Indian Colloq Micropal Strat 263-298

Shankaranaraya Guptha M V (1979) Sediments of the Western continental shelf of India- Environmental Significance Jour Geol Soc India 20 107-113

Sreenivas K, Raju B N Honappa and Reddi K R (1991) Ostracoda in the estiuraine sediments, Pulicat Lake esturay, east coast of India Jourl Geol Soc India 37 492-499

Subba Rao M (1960) Organic matter in marine sediments off east coast of India Bull AAPG 44 1705-1713

Subba Rao M and Mahadevan C (1957) Distribution of calcium carbonate in the marine sediments off Visakhapatnam Geol Dept Andhra Univ Waltair 149-152

Sverdrup H V, Johnson M W and Fleming R H (1942) The Oceans, Prentice Hall, New York, 1087

Trefethen J M (1950) Classifaication of sediments Amer Jour Sci 248 55-62

Venkata Rao T and Subba Rao M (1974) Recent foraminifera of 
Suddagedda Estuary, east coast of India Micropal 20398 419

Venkatesh Prabhu H, Hariharan V, Katti R J and Narayana A C (1997) Textural characteristics of near shore sediments of Honnavar, southwest coast of India Indian Jour Mar Sci 26 392-394
Venkatesh Prabhu H, Hariharan V, Katti R J and Narayana A C (1997) Textural characteristics of near shore sediments of Honnavar, southwest coast of India Indian Jour Mar Sci 26 392-394. 